J. Lake Sci. (湖泊科学), 2015, 27(2):319-326

http: //www. jlakes. org. E-mail : jlakes@niglas.ac.cn

(c) 2015 by Journal of Lake Sciences

\title{
一个分层水库温跃层的模拟与验证"
}

\author{
孙 昕, 王 雪, 许 岩, 解 岳, 黄廷林 \\ (西安建筑科技大学环境与市政工程学院,西安 710055)
}

\begin{abstract}
摘 要: 以西安金盆水库为例, 建立了分层水库水温结构的数值模拟方法, 并以实测数据进行模型验证. 运用 Fluent 软件 数值研究了不同短波辐射强度及短波辐射衰减系数条件下温跃层的形成过程与特性. 水库水面总传热量在春、夏季为正 值, 在秋、冬季为负值, 长波辐射是水面总传热量的主要影响因素, 短波辐射则是温跃层形成的主要影响因素. 随短波辐 射衰减系数的降低, 温跃层厚度增加, 温跃层内温度梯度减小, 短波辐射衰减系数值与实测的藻类浓度存在良好的正相 关性. 水库具有极限短波辐射强度, 温跃层内温差随水面短波辐射强度的增加呈现先增加后减小的变化趋势; 但水面短 波辐射强度过高时, 难以达到热平衡而形成稳定的温跃层.
\end{abstract}

关键词: 分层水库;温跃层; 影响因子;数值模拟

\section{Numerical simulation and verifications on thermal stratification in a stratified reservoir}

\author{
SUN Xin, WANG Xue, XU Yan, XIE Yue \& HUANG Tinglin \\ (School of Environmental and Municipal Engineering, Xi'an University of Architecture and Technology, Xi'an 710055, P.R. \\ China)
}

\begin{abstract}
Taking Jinpen Reservoir in Xi'an as a study case, a numerical simulation method for thermal structure of a stratified reservoir was developed and validated against the field data. The development and characteristics of the thermocline under various conditions of short wave radiation and bulk extinction coefficient for short wave radiation was numerically investigated by using a commercially-available software of Fluent. The net total surface heat transfer is positive in spring and summer, while negative in autumn and winter. The long wave radiation mainly contributes to the net total surface heat transfer, while the short one controls the development of the thermocline. The depth of the thermocline increased and the temperature gradient over the thermocline decreased as the bulk extinction coefficient decreased, and the bulk extinction coefficient is positively related to the algae concentration. There was a maximum value of the surface short wave radiation for a certain reservoir, the temperature difference between the top and bottom of the thermocline increased when the short wave radiation was below the maximum radiation, but it decreased when the short wave radiation was beyond the maximum radiation. Moreover, a heat balance and a stable thermocline can't be easily developed under higher short wave radiation.
\end{abstract}

Keywords: Stratified reservoir; thermocline; influencing factor; numerical simulation

水温是湖泊水库水质监测中一项非常重要的理化指标, 它与水中溶解氧 (DO)、化学需氧量 (COD) 等水 质参数密切相关, 也是湖泊水库分层研究中的重要参数, 水温的变化还直接影响湖泊水库的富营养化和生 态变化 ${ }^{[1-4]}$. 绝大多数深水型水库一般在夏、冬季节会普遍发生水温分层, 夏季典型的正向水温分层结构从 上到下依次为变温层、温跃层和等温层. 季节性水温分层是分层水库水质内源污染的主要诱因之一 ${ }^{[5-6]}$. 温 跃层会阻碍上下水层的物质和能量交换, 表层水体中较高浓度的溶解氧很难穿过温跃层而传递到底部水 体, 底部水体和底泥因各种化学、生物等作用而耗氧, 二者共同导致底部水体溶解氧浓度逐渐降低, 随温跃 层厚度增加和持续时间延长, 溶解氧浓度的降低程度增大, 底泥中氮、磷、有机物等污染物释放量越大, 内源

* 国家自然科学基金项目 (51178379,51278404)、国家科技支撑计划项目 (2012BAC04B02)、教育部高等学校博士学科 点专项科研基金项目 (20106120120012) 和西安建筑科技大学人才科技基金项目 (RC1130) 联合资助. 2014 - $03-$ 10 收稿;2014-07-02 收修改稿. 孙昕(1971 ), 男,博士, 教授;E-mail: xinsunn@ gmail. com. 
污染越严重 ${ }^{[6-8]}$. 当溶解氧浓度低于 $2 \mathrm{mg} / \mathrm{L}$ 时, 水库底泥中的无机和有机污染物会大量释放, 形成水库内源 污染, 在冬春交替季节 “翻库” 而污染整个水库水体 ${ }^{[9]}$. 因此, 研究温跃层的形成及其影响因素对进一步研究 破坏分层水库水质的演变和内源污染控制技术具有重要的理论和现实意义.

尽管国内外学者开展了大量水库水温预测模型和应用研究 ${ }^{[10-12]}$, 但很多模拟软件均不同程度地存在速 度场和能量场耦合难的问题, 多数只是注重模拟结果与实际数据的对比, 缺乏对影响温跃层形成主要因素 的研究与分析, 尤其是对于富营养化分层水库. 目前关于温跃层的研究主要针对海洋和浅水湖泊的水温观 测, 如陈希等 ${ }^{[13]}$ 、张文静等 ${ }^{[14]}$ 、赵保仁 ${ }^{[15]}$ 现场考察了净辐射通量、海潮、洋流对海洋温跃层形成的影响, 认 为净辐射通量的季节性变化是造成海洋跃层产生季节性变化的主要原因之一; 由洋流引起的海潮将海面处 高温水体带人下层, 加速温跃层的形成. Brett 等 $^{[16]}$ 针对水深较浅的 Mirror 湖和 Swan 湖, 提出了包含太阳辐 射、风速、水深、水体密度和比热容等因素的水温分层参数, 但未深人研究温跃层的形成机制. Lap 等 $^{[17]}$ 根据 对浅水湖泊的观测结果, 认为水温分层的形成与消失主要是由于风的影响和太阳辐射. Tuan 等 ${ }^{[18]}$ 发现风 速、风向对于浅水湖泊中热量的混合作用会产生一定影响. 余丰宁等 ${ }^{[19]}$ 对太湖温跃层形成因素的研究认为, 气温的变化会使得水温呈线性变化, 而大气湿度的增加会使水温呈指数变化; 目前, 仅在个别深水型湖泊和 水库进行了温跃层的现场观测和初步分析 ${ }^{[20-22]}$. Zhang 等 ${ }^{[20]}$ 根据千岛湖多年水温监测数据, 分析了该湖水 温及温跃层的月度和季节性变化规律, 建立了温跃层深度、厚度和强度与表层水温和水体透明度的经验模 型, 认为气候变化明显影响该湖水温结构. 学者们对抚仙湖水温分层进行了系统的长期观测 ${ }^{[23]}$, 对深水湖泊 中温跃层的相关特征作出了定义, 并根据实测数据, 分析了温跃层的形成与演变过程. 然而, 关于深水型分 层湖泊水库温跃层的形成特性及影响因素的系统研究尚未见报道.

本文应用商业 Fluent 软件 ${ }^{[24]}$ 并编写水体热交换的用户自定义函数 (UDF $)^{[25]}$ 对其进行了二次开发, 以 平均水深 $80 \mathrm{~m}$ 的西安金盆水库水体为对象, 系统研究不同表层短波辐射强度及藻类浓度条件下的水温结 构, 旨在研究和分析气象及环境因子对温跃层形成的影响, 为控制分层水库水质污染提供参考.

\section{1 数值模拟方法}

\section{1 水动力学控制方程}

采用 Fluent 软件自带的可压缩传热紊流模型,包括流体连续性方程、动量方程、能量方程和紊流方程, 其中紊流方程采用标准的 $\mathrm{k}-\varepsilon$ 紊流模型. 在浮力传热紊流中, 密度和粘度均随温度和压力变化, 但压力的影 响可忽略, 根据不同温度下水的密度和粘度数据, 建立水的密度和粘度与水温的函数关系, 采用 $\mathrm{C}$ 语言编写 UDF, 编译并加载到 Fluent 中.

\section{2 水体热交换模型}

水库水体内的热交换按性质通常分为对流、传导、辐射和蒸发 4 种,按影响的区域不同又可分为表面传 热和穿透传热两种. 大气长波辐射、蒸发和传导均属于表面传热, 表面传热一般影响深度不超过 $2 \mathrm{~m}$; 太阳短 波辐射则属于穿透传热,会作用于更深的水体. 实际上,表面 $0 \sim 2 \mathrm{~m}$ 处水温受表面传热和表面短波辐射影 响. 水温分层是表面传热和水下短波辐射传热共同作用的结果, 二者影响范围的有限性导致水温在一定水 深处出现跃降, 自上而下形成水温变幅较小的变温层、温度梯度较大的温跃层和水温相对恒定的等温层.

根据 Hodges 的水体热交换模型 ${ }^{[26]}$, 水体表面总的热交换量 $\left(Q_{\mathrm{S}}\right)$ 为长波辐射量 $\left(Q_{\mathrm{R}}\right)$ 、水面蒸发量 $\left(Q_{\mathrm{W}}\right)$ 、水面显热对流量 $\left(Q_{\mathrm{H}}\right)$ 之和, 即:

$$
Q_{\mathrm{S}}=Q_{\mathrm{R}}+Q_{\mathrm{W}}+Q_{\mathrm{H}}
$$

长波辐射量 $\left(Q_{\mathrm{R}}\right)$ 的计算公式为:

$$
\begin{gathered}
Q_{\mathrm{R}}=-\varepsilon_{(\text {water) }} \cdot \delta \cdot T_{(\text {water })}^{4}+\varepsilon_{(\text {air })} \cdot \delta \cdot T_{(\text {air })}^{4}\left(1-R_{\mathrm{t}(\mathrm{W})}\right)\left(1+0.17{C_{(\text {cloud })}}^{2}\right) \\
\varepsilon_{(\text {air })}=0.920 \times 10^{-5} T_{(\text {air })}^{2}
\end{gathered}
$$

式中, $T_{(\text {water })} 、 \varepsilon_{(\text {water }) 、} \varepsilon_{(\text {air })} 、 R_{\mathrm{t}(\mathrm{w})}(1 / C) 、 \delta 、 T_{\text {(air) }} 、 C_{\text {(eloud) }}$ 分别为水面 $0 \mathrm{~m}$ 处温度 $(\mathrm{K}) 、$ 水的辐射系数 $($ 取 0.96$) 、$ 大气的辐射系数、水面长波辐射反射率 (取 0.3 )、波兹尔曼常数 (取 $5.669 \times 10^{-8} \mathrm{~W} /\left(\mathrm{m}^{2} \mathrm{C}^{4}\right)$ ) 、水面上 $2 \mathrm{~m}$ 处气温 $(\mathrm{K})$ 、云层覆盖率( 取 0.17 ). 
水面蒸发量 $\left(Q_{\mathrm{W}}\right)$ 的计算公式为:

$$
Q_{\mathrm{W}}=L \cdot C_{\mathrm{W}} \cdot u_{\text {(wind) }} \cdot \rho_{\text {(air) }} \frac{0.622 \times 10^{\left\{\frac{0.7859+0.03477 T}{1+0.00412 T}-3\right\}}}{P}\left(R_{\mathrm{h}}-1\right)
$$

式中, $L 、 C_{\mathrm{W}} 、 \rho_{(\text {air })} 、 u_{(\text {wind })} 、 P 、 R_{\mathrm{h}}$ 分别为蒸发潜热 (取 $2.5 \times 10^{6} \mathrm{~J} / \mathrm{kg}$ )、蒸发传热系数 (取 $\left.0.0014 \mathrm{~kg} / \mathrm{m}^{3}\right)$ 、空气 密度 (取 $1.225 \mathrm{~kg} / \mathrm{m}^{3}$ )、水面处的风速 $(\mathrm{m} / \mathrm{s}$ )、一个标准大气压 $(\mathrm{pa}) 、$ 相对湿度.

水面显热对流量 $\left(Q_{\mathrm{H}}\right)$ 的计算公式为:

$$
Q_{\mathrm{H}}=C_{\mathrm{H}} \cdot c_{\mathrm{p}(\text { air) }} \cdot \rho_{(\text {air })} \cdot u_{(\text {wind })}\left(T_{(\text {air_r })}-T_{(\text {water })}\right)
$$

式中, $C_{\mathrm{H}} 、 c_{\mathrm{p}(\text { air) }} 、 T_{(\text {air } r \text { r) }}$ 分别为显热传导体积系数 (取 0.0014 )、水的定压比热 (取 $1003 \mathrm{~J} / \mathrm{kg} \mathrm{C}$ )、水面上空气的 干球温度 $(\mathrm{K})$, 其余同上.

水面太阳净短波辐射量 $\left(Q_{\mathrm{sw}}(S)\right)$ 和水下短波辐射量 $\left(Q_{\mathrm{sw}}(Z)\right)$ 的计算公式为:

$$
\begin{gathered}
Q_{\mathrm{sw}}(S)=Q_{(\text {sw_surface })}\left(1-0.65 C_{(\text {cloud })}{ }^{2}\right)\left(1-R_{\mathrm{t}(\mathrm{sw})}\right) \\
Q_{\mathrm{sw}}(Z)=Q_{\mathrm{sw}}(S) \exp \left\{-\eta_{\mathrm{e}}(S-z)\right\}
\end{gathered}
$$

式中, $R_{\mathrm{t}(\mathrm{sw}) 、} Q_{\text {(sw_surface) }} 、 Q_{\mathrm{sw}}(S) 、 \eta_{\mathrm{e}}$ 分别为无量纲的短波辐射表面反射率、通过水面的总短波辐射量 $\left(\mathrm{W} / \mathrm{m}^{2}\right)$ 、透过水面的净短波辐射 $\left(\mathrm{W} / \mathrm{m}^{2}\right)$ 、衰减系数 $\left(\mathrm{m}^{-1}\right)$.

\section{3 金盆水库及计算网格、初始条件与边界条件}

研究对象为西安金盆水库,该水库平均水深 70 100 $\mathrm{m}$, 日供水量 $80 \times 10^{4} \mathrm{~m}^{3}$, 为西安市主要饮用水水源. 近年来, 该水库水体富营养化程度不断加剧, 其中氮、磷营养盐浓度阶段性超标, 有机质含量上升, 藻类季节 性高发等水质问题尤为突出, 处于中富营养化状态, 7-8 月表层藻类浓度可高达 $2 \times 10^{7} \sim 3 \times 10^{7} \mathrm{cells} / \mathrm{L}^{[4]}$. 以坝前主库区的断面水体为研究对象, 所研究水域半径约为 $500 \mathrm{~m}$. 水库地形采用中海达 RTK 系统测量. 为 长期监测金盆水库水质, 在主库区设置 5 个监测点, 本文所用数据均取自引水塔和主坝之间的 $\mathrm{S} 1$ 点 $^{[4]}$, 该 点约位于图 1 所示断面宽度的 $1 / 3$ 处 (近右侧). 水温采用美国 HACH Hydro-Lab DS5 型多参数水质分析仪 现场监测, 垂向测点间距一般为 5 10 m; 藻类现场取样 (1 L), 采用鲁哥试剂 (15 ml) 固定后, 带回实验室进 行显微镜计数分析, 垂向测点分别位于水 面下方 $0.5 、 5 、 30 \mathrm{~m}$, 频率 $1 \sim 3$ 次, 本文所 用藻类浓度为水深 $0.5 \mathrm{~m}$ 处值. 采用 GAMBIT 构建水域断面的实际地形网格, 针对水 深月际变幅较小的 $3 、 5 、 7 、 9$ 和 12 月, 水深 约为 $80 \sim 88 \mathrm{~m}$, 图 1 为水深 $80 \mathrm{~m}$ (7 月) 坝 前断面的二维网格, 共有 12835 个节点

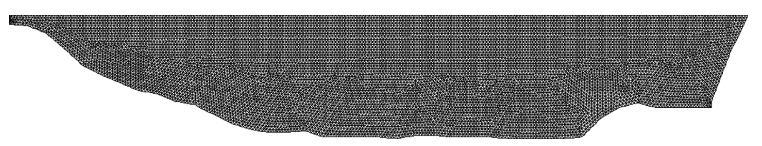

图 1 坝前断面二维网格

Fig. 1 Two-dimensional meshes of a cross-section near the main dam (nodes), 12600 个单元 (cells).

该河道型水库上游河道长近 $40 \mathrm{~km}$, 根据水库坝前特征计算出流量和断面面积, 进口采用速度人口边界 (velocity-inlet), 计算的断面平均流速约为 $0.0002 \mathrm{~m} / \mathrm{s}$, 由此计算左上侧等效进水口和右下侧出水口断面的平 均流速. 水库边壁和底部都采用无滑移固体壁面条件 (Wall), 设置为绝热墙, 其当量粗䊁高度取 $0.0003 \mathrm{~m}$.

根据金盆水库底部水温资料 (断面中心处), 将水库水体初始温度设为 $279.15 \mathrm{~K}$, 开启能量方程 (energy equation), 采用 $\mathrm{k}-\varepsilon$ 紊流模型进行计算,通过水体的自然热交换实现分层. 表面和水下传热过程采用 $\mathrm{C}$ 语言 编写的 UDF 写人, 表面传热项由 DEFINE_PROFILE (name, thread, i) 宏将方程通过 Heat Flux 项写人, 水下传 热通过 DEFINE_SOURCE(name, cell, thread, dS, eqn) 宏写人水体源项 (source terms).

\section{4 水库温跃层影响因子及模拟参数}

在分层水库地形和水文条件相对固定的条件下, 水库温跃层的形成是水库内热力和动力过程共同作用 的结果 ${ }^{[23,27]}$, 受各种气象和环境等因素的影响, 如风力混合、水体清澈度 (藻华堆积) 、大气温度、云量、太阳 辐射强度等 ${ }^{[27]}$; 水库的运行调度 (如进出水流)、原位水质控制设施的运行等也会影响温跃层的形成与破 坏; 自然水文事件 (如夏季汛期暴雨径流和/或冬春季融雪径流等) 也在一定程度上影响温跃层的变化 ${ }^{[28]}$. 
本文以中富营养化的金盆水库为案例, 因该地区春、秋季一般均为 $20 \mathrm{~d}$ 左右, 故未将气温作为主要因素进行 研究, 而是重点研究气象因子 (如太阳辐射强度、风速等) 以及水质因子 (藻类浓度) 对温跃层形成的影响,

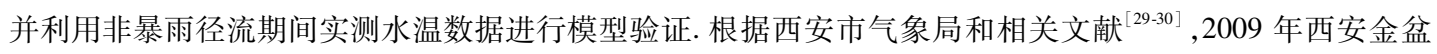
水库库区相关气象和水文参数如表 1 所示.

表 12009 年周至地区相关气象和水文资料(月均)

Tab. 1 Meteorological and hydrological data of Zhou Zhi area, 2009(monthly-averaged)

\begin{tabular}{cccccc}
\hline 月份 & 气温 $/{ }^{\circ} \mathrm{C}$ & 短波辐躬强度 $/\left(\mathrm{W} / \mathrm{m}^{2}\right)$ & 水深 $/ \mathrm{m}$ & 表层水温 $/{ }^{\circ} \mathrm{C}$ & 风速 $/(\mathrm{m} / \mathrm{s})$ \\
\hline 3月 & 10.8 & 164.6 & 80 & 10.5 & 0.21 \\
5月 & 20.0 & 181.4 & 80 & 17.2 & 0.32 \\
7月 & 26.3 & 197.4 & 80 & 28.0 & 0.50 \\
9月 & 19.9 & 117.0 & 86 & 19.2 & 0.35 \\
12 月 & 1.9 & 91.3 & 85 & 8.0 & 0.46 \\
\hline
\end{tabular}

根据改进的水体热交换模型, 将以上气象条件参数通过 UDF 导人, 直接进行基于 Fluent 的数值计算, 时 间步长选取 $10 \mathrm{~s}$; 由于实际水库中水体形成分层过程较慢, 每个条件下运行 $30 \mathrm{~d}$ 左右 (即 $259200 \mathrm{~s}$ ), 通过温 度云图观察温跃层的形成和变化特性. 模型垂向深度间隔约为 $2 \mathrm{~m}$, 由于表面传热仅仅作用于水面下 $1 \sim 2 \mathrm{~m}$ 深度处,故忽略可能产生的能量跃变问题.

\section{2 结果与分析}

\section{1 模型验证及温跃层演变}

根据王银珠等的研究结果 ${ }^{[21]}$, 将垂向的温度梯度大于 $0.2^{\circ} \mathrm{C} / \mathrm{m}$ 的水层定义为温跃层. 利用表 1 所示基 础资料并对照在金盆水库库区断面中实测的垂向水温分布数据 ${ }^{30]}$, 变化不同的短波辐射衰减系数进行水温 模拟, 对比不同条件下模拟的水温结构和实测的水温结构, 对短波辐射衰减系数进行参数率定, 发现不同季 节水温结构的模拟结果与实测结果吻合良好, 对弱分层、较强分层和混合阶段的水温结果进行对比, 发现其 相关系数均在 0.91 以上,说明了这种模拟方法的准确性 (图 2).

3 月水库处于弱分层期, 温跃层约位于水深 $3 \sim 8 \mathrm{~m}$ 处, 温跃层内温差约为 $3^{\circ} \mathrm{C} .7$ 月水库处于强分层期, 温跃层约位于水深 $3 \sim 19 \mathrm{~m}$ 处, 温跃层内温差约为 $20^{\circ} \mathrm{C}$, 水深 $2.5 \mathrm{~m}$ 内为上部变温层, 水深 $19 \mathrm{~m}$ 以下为等温 层. 9 月水库水温分层不断减弱, 温跃层约下潜至水深 $30 \sim 70 \mathrm{~m}$ 处, 温跃层内温差约为 $8^{\circ} \mathrm{C}$, 水深 $30 \mathrm{~m}$ 内为 变温层. 12 月, 冬季气温较低, 上下层水体温差微小 (约 $1.9^{\circ} \mathrm{C}$ ), 基本处于等温状态, 水温分层结构消失, 不 存在温跃层. 对照 2009 年实测数据, 温跃层的形成过程更为完整, 冬、春季节整个库区水温基本相同, 不存 在温跃层; 夏、秋季节水面和水底开始存在一定温差, 极易形成水温分层, 尤其是 7-8 月, 水面和底部水体 温差最大, 水温分层最为强烈, 温跃层最为稳定、厚度最大.

对比国内关于深水湖泊的开创性研究成果 ${ }^{[21]}$, 金盆水库温跃层的垂向演变特性与平均水深 $87 \mathrm{~m}$ 的抚 仙湖情况大体类似, 只是该湖地处中亚热带半湿润季风气候区, 水温常年高于 $12^{\circ} \mathrm{C}$, 不同于金盆水库. 抚仙 湖 $1 、 2$ 月份处于完全混合期, 其余月份水温自上而下均可分为变温层、温跃层和等温层, 但温跃层深度、厚 度以及层内温度梯度因季节而异, 增温期温跃层位置较浅、厚度较大、温度梯度较小, 升温期温跃层位置下 移、厚度变薄、温度梯度增大. 此外, 该湖水面宽广, 温跃层特征也在水平方向略有差异, 与水面较小的金盆 水库不同.

\section{2 风对温跃层形成的影响}

风在一定水深范围内、一定条件下影响着水面的混合强度和水体能量的耗损,一般风驱动的混合作用 使得上部水体水温趋于均匀, 在中部形成稳定度很大的温跃层, 风对浅水湖库和海洋水温分层影响较 $大^{[20,27]}$. 具体而言, 风对水温的影响至少体现在 3 方面:1) 影响表面传热;2）影响波浪和湖流, 造成上下层 水层交换;3）改变水柱中光衰减物质组成,造成短波辐射衰减系数变化,影响短波辐射传热量.

根据表 1 所示金盆水库气象及水文资料,应用根据 Hodges 的水体热交换模型,分别计算 $3 、 5 、 7 、 9 、 12$ 月 
水温 $/{ }^{\circ} \mathrm{C}$

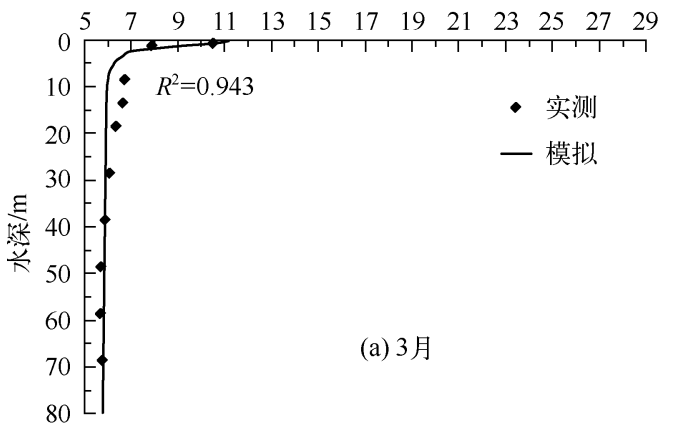

水温 $/{ }^{\circ} \mathrm{C}$
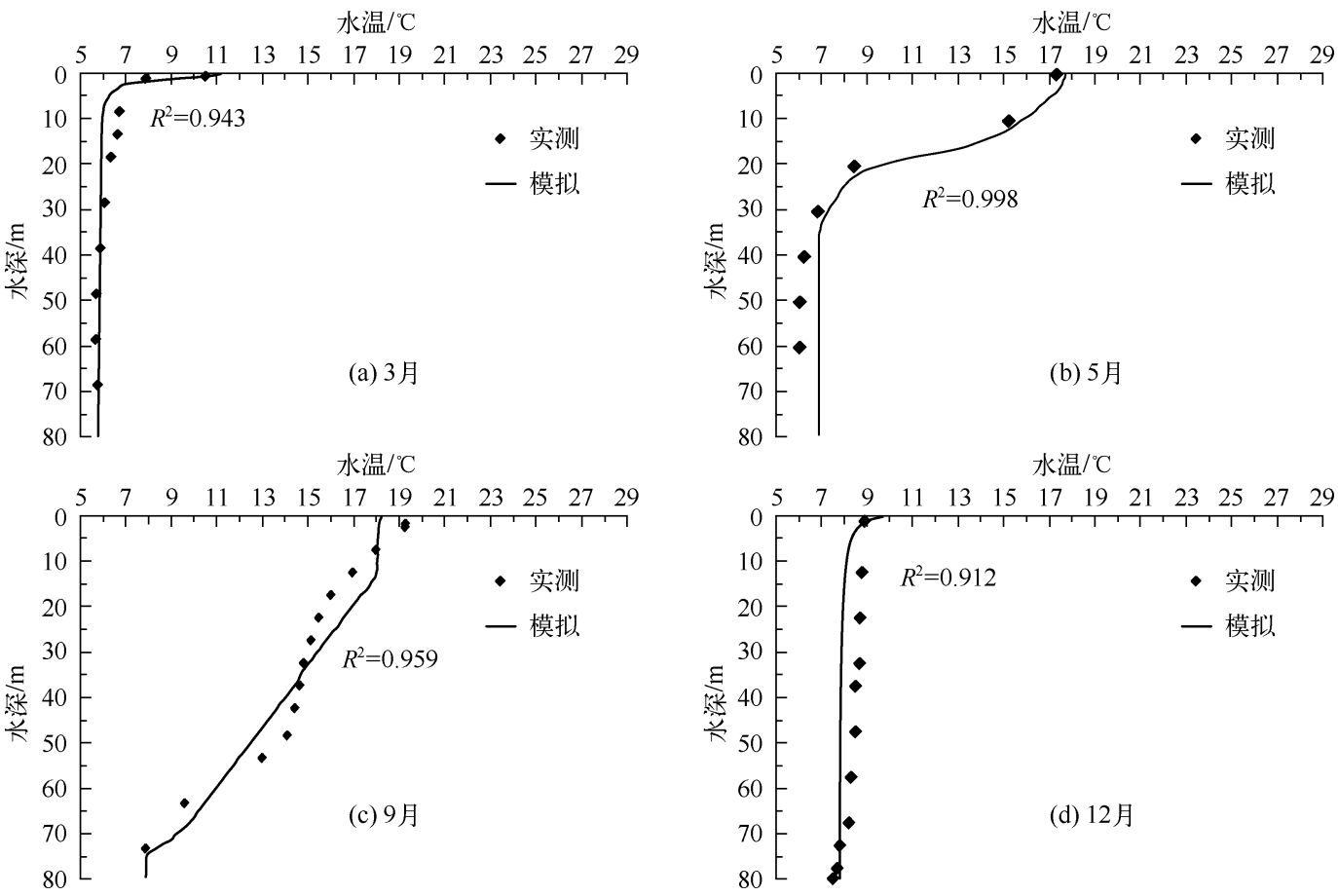

图 2 模拟的不同月份水温垂向结构

Fig. 2 Simulated thermal structures over the water depth of various months

水库表面各项传热量和总传热量,并绘制 于图 3. 根据传热量计算结果, 如果不计表 面的短波辐射传热量, 长波辐射传热量约 占总传热量的 $95 \%$ 100\%, 说明长波辐射 传热量是决定表面热量散失的绝对主导 因素,而水面蒸发和热对流引起的传热量 对水面处热量散失的影响极其微小. 根据 段誉等的研究 ${ }^{[31]}$, 当水面总传热量为负 值时, 风的影响较小, 基本可以忽略; 另 外,金盆水库实际气象条件 (表 1 ) 表明, 风速较小,水面蒸发和热对流引起的传热 量与风速相关, 因此风对金盆水库水温结 构的影响可忽略不计. 如果考虑表面的短 波辐射传热量,则在春、夏季节,水面总传

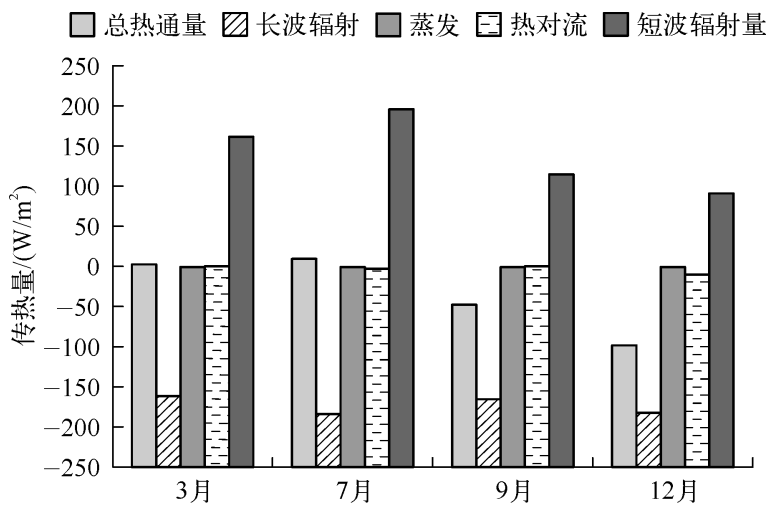

图 3 不同月份各项表面传热量

Fig. 3 Surface heat transfer fractions of various months 热量为正值,水面将处于加热状态, 表层水的密度将随水温增加而减少, 温跃层将会变厚; 在秋、冬季节, 水 面总传热量为负值, 水面处于散热状态, 温跃层变稀薄, 等温层加深. 在本研究条件下, 坝前主库区水面面积 和风速均较小,可以认为风的作用对金盆水库温跃层形成的影响较小,不同于浅水环境 ${ }^{[32]}$.

\section{3 短波衰减系数对温跃层形成的影响}

在本模拟中,水库水面净热交换量为负值,说明水库温跃层的形成主要取决于水体受纳的短波辐射传 热量, 影响短波辐射传热量的主要参数是水面短波辐射强度和水体短波衰减系数. 先以表层和底部水温差 别最大的 7 月为例, 此时水体分层较强烈,利用表 1 所示的实际气象资料, 分别取短波辐射衰减系数为 0.5 、 $2.0 、 3.0$ 和 $4.0 \mathrm{~m}^{-1}$ 进行模拟, 运行一个月后的水温结构如图 4 所示. 
随着短波辐射衰减系数从 0.5 增加到 4.0 , 在表层水深 $5 \mathrm{~m}$ 范围内, 虽然不同条件下的水体水温总体基 本在 $26^{\circ} \mathrm{C}$ 附近; 但表层水温仍有略降低的趋势, 水深 $5 \mathrm{~m}$ 处水温约从 $26.5^{\circ} \mathrm{C}$ 降低到 $25^{\circ} \mathrm{C}$; 随着水深的增加, 水温随短波辐射衰减系数的增加而降低的趋势更为明显,水深 $20 \mathrm{~m}$ 处水温约从 $18^{\circ} \mathrm{C}$ 降低到 $9.5^{\circ} \mathrm{C}$. 依据公 式 (7), 短波辐射传热量随水库水深的增加而呈指数衰减, 衰减的快慢主要与短波辐射衰减系数有关, 短波 辐射衰减系数越大, 单位水深内藻类及其他悬浮物等吸收的热量越大, 水体实际受纳的短波辐射热量越小, 表现为水温增加值越小, 太阳短波辐射的穿透深度越小. 模拟结果与理论分析相一致.

水温 $/{ }^{\circ} \mathrm{C}$

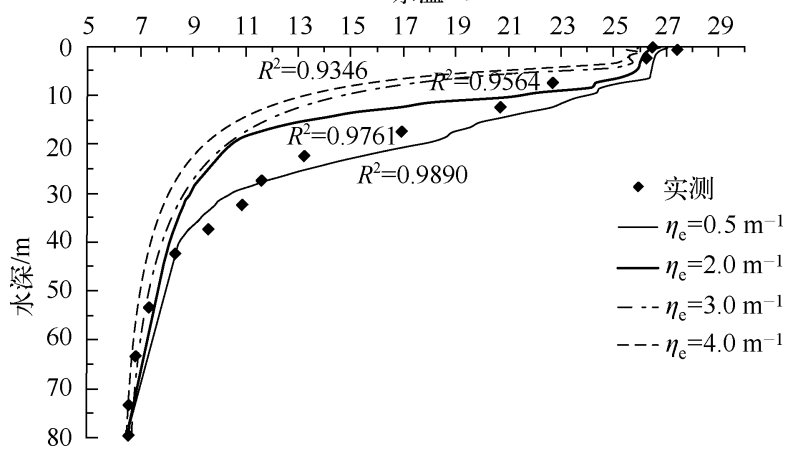

图 4 短波辐射衰减系数对水温结构的影响

Fig. 4 Effect of attenuation coefficient of shortwave radiation on thermal structure

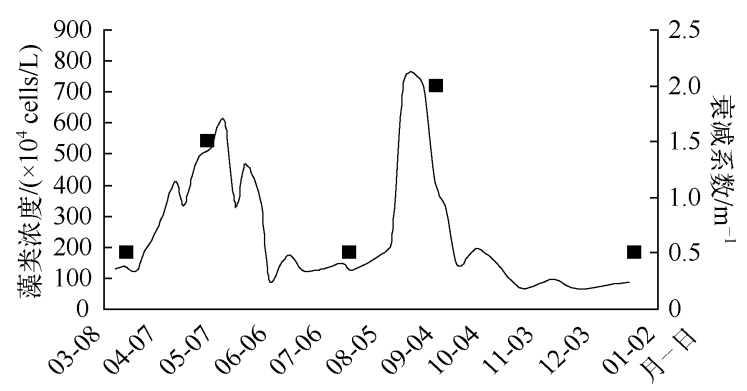

图 5 短波辐射衰减系数与水库藻类浓度的关系

Fig. 5 Relationship between attenuation coefficient of shortwave radiation and concentration of algae

根据图 4 所示的水温结构,短波辐射衰减 系数对温跃层的形成有直接影响. 如以水温 $7 \sim 9^{\circ} \mathrm{C}$ 作为等温层水温, 则当短波辐射衰减系 数分别为 $0.5 、 2.0 、 3.0$ 和 $4.0 \mathrm{~m}^{-1}$ 时, 温跃 层位置分别约为水下 $8 \sim 43 \mathrm{~m} 、 5 \sim 35 \mathrm{~m} 、 4 \sim$ $30 \mathrm{~m} 、 3 \sim 21 \mathrm{~m}$, 跃层内温度梯度分别为 $0.50 、 0.57 、 0.63 、 0.92^{\circ} \mathrm{C} / \mathrm{m}$. 利用表 1 所示 其他 4 个月份的基础气象和水文资料, 变化 短波辐射衰减系数进行水温模拟, 得到的 温跃层特性也较为相似, 即随短波辐射衰 减系数的降低, 温跃层位置下移、温跃层厚 度降低, 温跃层内温度梯度逐渐增加.

根据不同短波辐射衰减系数条件下模 拟的垂向水温分布, 对比实测的垂向水温 分布数据 ${ }^{[18]}$, 得出针对 $3 、 5 、 7 、 9$ 和 12 月的 最适宜短波辐射衰减系数分别为 $0.5 、 1.5$ 、 $0.5 、 2.0$ 和 $0.5 \mathrm{~m}^{-1}$. 国外对湖泊水库水体短 波辐射衰减系数的参考范围较大, 从清澈的 贫营养湖泊的 $0.2 \mathrm{~m}^{-1}$ 到浑浊的富营养湖泊 的 $4.0 \mathrm{~m}^{-1[27]}$, 本文校验的短波辐射衰减系 数值亦与其相近. 将不同月份经过校验的短 波辐射衰减系数和实测藻类浓度共同绘于 图 5 ,可以看出短波辐射衰减系数大小与藻 类浓度高低的对应关系良好, 较好地反映出 中富营养化水库不同季节藻类生长情况与 短波辐射衰减状况的关系. 水库水的浊度很

低, 非汛期一般为 $10 \mathrm{NTU}$ 左右, 无机颗粒对短波辐射衰减系数的影响可以忽略, 藻类成为影响短波辐射衰 减系数的主要物质,故藻类浓度的增加会影响短波辐射的水下穿透量, 从而造成短波辐射衰减系数降低, 影 响温跃层位置. 水质监测结果显示, 藻类浓度随水深增加, 表现出先增加至水深 $5 \mathrm{~m}$ 处的峰值, 然后降低, 并 在 $15 \mathrm{~m}$ 左右约降为峰值的 $1 \%$. 尽管藻类浓度在垂向分布不均,但由于短波辐射热量呈指数型衰减,在夏季 净短波辐射较强的时节, 短波辐射能量的消耗主要集中在表层水体, 故垂向采用统一的短波辐射衰减系数 对水温预测结果的影响较小.

\section{4 短波辐射强度对温跃层形成的影响}

根据表 1 所示水库 7 月的气象和水文资料, 取实测短波辐射强度 $197.4 \mathrm{~W} / \mathrm{m}^{2}$ 和经过校验的短波辐射衰 减系数 $0.5 \mathrm{~m}^{-1}$, 变化水面短波辐射强度 $100 、 400 、 800 \mathrm{~W} / \mathrm{m}^{2}$ 进行水温模拟, 虽然所取得的短波辐射强度变 化范围较大, 超出实测范围, 但利用极端条件的水温模拟数据, 可更全面、直观地评判短波辐射强度对温跃 层的影响趋势, 为后续短波辐射强度的相关影响研究提供参考. 图 6 表示水面短波辐射强度与上下层水体 温差的关系. 当水面短波辐射强度为 $100 、 400 \mathrm{~W} / \mathrm{m}^{2}$ 时, 上下层水体温差随时间的推移而逐渐增加, 但增幅减 
小, $20 \mathrm{~d}$ 后趋于稳定, 说明在次模拟条件下, 水体热交换达到相对平衡. 当水面短波辐射强度为 $800 \mathrm{~W} / \mathrm{m}^{2}$ 时,上下层水体温差也随时间的推移而增加, 但增幅并未减小, $20 \mathrm{~d}$ 后水体温差仍在继续增加. 随着短波辐 射传热过程的延续, 水面及以下水体吸收的热量增加, 导致表层水温增加, 上下层温差随之增加. 根据公式 (7), 在短波辐射衰减系数相同的情况下, 短波辐射在水下的衰减速率相同, 并呈指数型衰减, 可以看出在夏 季净短波辐射较强的时节, 短波辐射能量在穿透水下 $40 \mathrm{~m}$ 左右时, 能量消耗达 $90 \%$, 水体受纳的短波辐射 传热量理论上主要与水面短波辐射强度有关, 从而上下层水体温差随短波辐射强度的增加而增加.

图 6 表明,水库可能存在一个水面短波辐射 强度极值 $Q_{\mathrm{S}} \in[400,500]$. 在较低的水面短波辐 射强度 $\left(\leqslant 400 \mathrm{~W} / \mathrm{m}^{2}\right)$ 下, 随着时间的推移, 水面 短波辐射强度越高, 水面处吸收的热量越多, 水面 处水温增加; 由于短波辐射强度在水深方向呈指 数关系衰减, 水体垂向各层吸收的能量向下递减, 当短波辐射强度小于水库辐射强度极值时, 表层 水温因不断吸收短波辐射而增加, 但能量来不及 作用到水底, 从而上下层水体温差逐渐增大, 即 上下层水体温差与水面短波辐射强度呈正相关. 在较高的水面短波辐射强度 $\left(>400 \mathrm{~W} / \mathrm{m}^{2}\right)$ 时, 当短波辐射强度高于水库短波辐射强度极值时, 由于水体吸收的热量较多, 会影响到底部水体温 度, 使底部水温也增加, 在一定的传热时间内, 导

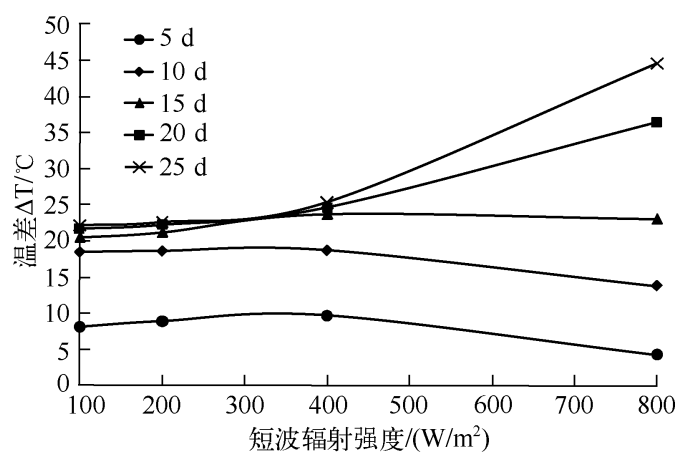

图 6 不同短波辐射强度条件下的上下层水体温差

Fig. 6 Water temperature difference between the upper and lower water layers under various shortwave radiation intensities 致上下层水体温差减小; 而随着传热过程的继 续, 受较高的水面短波辐射强度影响, 表层水温增幅会高于底部水温增幅, 导致后期上下层水温差增大. 上 下层水体温差随水面短波辐射强度的增加而呈现先增大后减小的趋势, 在太湖地区也曾有所观测: 在太湖 地区, 当短波辐射强度增大到 $700 \mathrm{~W} / \mathrm{m}^{2}$ 时, 太阳辐射强度会使得垂向水体受到均匀加热, 温差降低, 产生短 波辐射极值 ${ }^{[32]}$.

对比本文初步得出的水库短波辐射强度极值与太湖地区 ${ }^{[31]}$ 报道的值, 可以发现水库水温分层的形成与 水面短波辐射的关系较为密切, 上述变化过程应该还会与水库或湖泊的水深及不同纬度带上的气象与地质 要素等有关, 具体关系仍需要进一步研究与讨论; 但是现有结果表明, 水面短波辐射强度对水温结构和温跃 层的形成有重要影响, 当水面短波辐射强度超过极值时, 很难形成稳定的温跃层. 表 1 资料显示, 金盆水库 地区短波辐射强度不高 (约 $200 \mathrm{~W} / \mathrm{m}^{2}$ ), 水深较大 (约 $80 \mathrm{~m}$ ), 故在季节交替时易形成稳定的温跃层, 不同于 浅水环境的分层情况.

\section{3 结论}

1) 通过模型参数率定, 模拟研究了水温结构与温跃层随季节的变化,温跃层从春季气温回升逐步形成, 在夏季形成稳定分层、温跃层厚度最大, 秋季随着气温下降而逐步下潜, 至冬季再次消失. 模拟结果对水库 水质演变和内源污染控制研究具有重要的参考价值和指导意义.

2) 在本模拟条件下, 水库水面长波辐射、蒸发和传导传热量总和为负值, 长波辐射量约占表面总传热量 的 $95 \%$ 100\% , 风基本不影响金盆水库温跃层的形成过程; 短波辐射是影响温跃层形成的主要因素.

3 ) 经校验的短波辐射衰减系数值与实测的藻类浓度存在良好的正相关性,二者的年际变化相互一致; 随短波辐射衰减系数的降低, 温跃层位置下移、厚度增加, 层内温度梯度减小.

4) 水面短波辐射强度对温跃层形成的影响较为复杂, 不同类型水库具有不同的极限短波辐射强度, 温 跃层内温差随水面短波辐射强度的增加呈现先增加后减小的变化趋势; 但水面短波辐射强度过高时, 难以 达到热交换平衡, 对形成稳定温跃层有重要指示作用. 


\section{4 参考文献}

[ 1 ] Burns NM, Rockwell DC, Bertram PE et al. Trends in temperature, secchi depth, and dissolved oxygen depletion rates in the central basin of Lake Erie, 1983 -2002. Journal of Great Lakes Research, 2005, 31 (Suppl. 2) :35-49.

[ 2 ] Liu X, Lu XH, Chen YW. The effects of temperature and nutrient ratios on Microcystis blooms in Lake Taihu, China: An 11-year investigation. Harmful Algae, 2011, 10 (3):337-343.

[ 3 ] Qin BQ, Gao G, Zhu GW et al. Lake eutrophication and its ecosystem response. Chinese Science Bulletin, 2013, 58(9) : $961-970$.

[ 4 ] 马 越,郭庆林,黄廷林等. 西安黑河金盆水库季节性热分层的水质响应特征. 水利学报,2013,44(4):406-415.

[5] 黄廷林,丛海兵,柴蓓蓓. 饮用水水源水质污染控制. 北京: 中国建筑工业出版社,2010.

[6] 孙 昕, 黄廷林. 湖泊水库水体污染控制. 武汉:湖北科学技术出版社,2013.

[ 7 ] 吴雅丽,许 海,杨桂军等. 太湖水体氮素污染状况研究进展. 湖泊科学, 2014,26(1):19-28.

[ 8 ] Fernandez RL, Bonansea M, Cosavella A et al. Effects of bubbling operations on a thermally stratified reservoir: Implications for water quality amelioration. Water Science and Technology, 2012, 66(12) : 2722-2730.

[ 9 ] Cong HB, Huang TL, Chai BB et al. A new mixing-oxygenating technology for water quality improvement of urban water source and its implication in a reservoir. Renewable Energy, 34(9) : 2054-2060.

[10] Midhat H, Heinz GS. Lake water temperature simulation model. Journal of Hydraulic Engineering, 1993, 119(11): 1251-1273.

[11] 任华堂,陈永灿,刘昭伟. 大型水库水温分层数值模拟. 水动力学研究与进展: A 辑,2007,22(6):667-675.

[12] Politano M, Haque MDM, Weber LJ. A numerical study of the temperature dynamics at McNary Dam. Ecological Modelling, 2008, 212(3/4) : 408-421.

[13] 陈 希,沙文钰,李 妍. 南海北部海区温跃层分布特征及成因的初步分析. 海洋预报,2001,18(4):9-17.

[14] 张文静,沙文钰. 黑潮对环台湾岛海域温跃层影响的数值研究. 海洋预报,2001,18(3):17-24.

[15] 赵保仁. 渤、黄海及东海北部强温跃层的基本特征及形成机制的研究. 海洋学报, 1989,11(4):401-410.

[16] Brett FB, Thomas T. Predicting the onset of thermal stratification in shallow inland waterbodies. Aquatic Sciences, 2009, 71 (1) : 65-79.

[17] Lap BQ, Tuan NV, Hamagamik et al. Formation and disapperance of thermal stratification in a small shallow lake. Journal of the Agriculture Kyushu University, 2009, 54(1): 251-259.

[18] Tuan NV, Hamagamik K, Mori K et al. Mixing by wind-induced flow and thermal convection in a small, shallow and stratified lake. Paddy and Water Environment, 2009, (7) : 83-93.

[19] 余丰宁,蔡启铭,徐勇积. 太湖水温模型和气象参数对水温的影响. 海洋与湖沼, 1993,24(4):393-399.

[20] Zhang YL, Wu ZX, Liu ML et al. Thermal structure and response to long-term climatic changes in Lake Qiandaohu, a deep subtropical reservoir in China. Limnology and Oceanography, 2014, 59(4) : 1193-1202.

[21] 王银珠, 誉培民. 抚仙湖水温跃层的初步研究. 海洋湖沼通报, 1982,4(4):1-9.

[22] Vassilis ZA, Soultana KG. Simulation of water temperature and dissolved oxygen distribution in Lake Vegoritis, Greece. Ecological Modelling, 2003, 160(1/2) : 39-53.

[23] 中国科学院南京地理与湖泊研究所. 抚仙湖. 北京: 海洋出版社, 1990 .

[24] Fluent Inc. FLUENT User's Guide. Lebanon: Flunet Inc., 2006.

[25] Fluent Inc. FLUENT User Defined Function Manual. Lebanon: Flunet Inc. , 2006.

[26] Hodges BR. Heat budget and thermodynamics at a free surface. Centre for Water Research, The University of Western Australia, 1999.

[27] Fischer HB, List JE, Koh CR et al. Mixing in inland and coastal waters. London: Academic Press, 1979.

[28] Huang TL, Li X, Rijnaarts H et al. Effects of storm runoff on the thermal regime and water quality of a deep, stratified reservoir in a temperate monsoon zone, in Northwest China. Science of The Total Environment, 2014, 485/486: 820-827.

[29] 吴林荣, 江志红, 鲁洣平等. 陕西太阳总辐射的计算及分布特征.气象科学, 2009,29(2):187-191.

[30] 邱二生. 黑河水库水质及藻类监测和水体分层研究 [学位论文].西安:西安建筑科技大学,2010.

[31] 段 誉,杨坤德. 南海等温层深度时空分布成因研究. 声学技术, 2011,30(6):95-96.

[32] 赵林林,朱广伟, 陈元芳等. 太湖水体水温垂向分层特征及其影响因素. 水科学进展,2011,22(6):844-850. 